American Journal of Applied Sciences 1 (1): 1-4, 2004

ISSN 1546-9239

(C) Science Publications, 2004

\title{
The Mechanism of Stock Market Integration: Evidence for the Taiwan and U.S. Stock Market
}

\author{
Min-Hsien Chiang, Rung-Ho Lai and Hsiao-Ching Lee \\ Institute of International Business, National Cheng Kung University, Taiwan
}

\begin{abstract}
This study investigates the sources of the comovement of the Taiwan and U.S. stock market. The empirical evidence shows that both economic fundamentals and equity risk premiums can act as transmission mechanisms of both markets. In the meantime, the financial integration is much stronger than real economic integration. Moreover, the deregulation of foreign investments in Taiwan and the Southeast Asian financial crisis in 1997 did not alter the transmission mechanisms of real economic and equity risk premium factors.
\end{abstract}

Key words: Market integration, Asian financial crisis, Transmission

\section{INTRODUCTION}

The issue regarding the integration of international stock market has drawn a lot of attention for past decades $^{[1-4]}$. It is believed that the diversification strategy of investments works better when invested markets are less correlated. The stock markets in the world, however, become more correlated due to trend of deregulation of capital flows, economic zone integration and worldwide financial market cooperation. Previous studies consistently show that comovements across major stock market indices really exist and are increasing over time ${ }^{[5,6]}$. This phenomenon is not restricted to the periodicity of the data ${ }^{[7]}$. For those studies investigating the international stock market linkages, most of them focus on the lead-lag issue $^{[8-10]}$ but few addresses the issue regarding the sources of such long-term comovements.

Some studies do touch the issue about the sources of comovements. Adopting ${ }^{[11]}$ excess return decomposition $^{[3]}$, show that there is substantial real and financial integration between the U.S. and the U.K., ${ }^{[12]}$ finds that the U.K. economy follows the economic performances of the U.S. while there is a fair correspondence between security returns of the U.S. and the U.K. concentrating on the U.S. and three European stock markets (London, Paris and Frankfurt), ${ }^{[7]}$ uncovers that correlations between these stock markets are a result of their real economic linkages. Meanwhile, there exists a greater proliferation of international financial linkage in the short run. And this short run linkage has less to do with macroeconomic fundamentals ${ }^{[13]}$. Analyze the longterm interaction between three European monetary system countries and find that stock market display long-term comovements. However, such relationships cannot be attributed to economic variables too much.

Therefore, considering the limited explanatory power of the economic linkage, we suspect that the increasing integration of international stock markets may be explained by linkages of economic forces but not all of it. For example, the market crash on the NYSE in October 1987 cased worldwide stock markets to plunge uniformly despite its despite its domestic nature $^{[14,15]}$. In addition, ${ }^{[3]}$ showed that international linkages seem to come from the comovement of equity risk premiums instead of real economic linkages ${ }^{[7]}$. Also uncovered considerable short run responses that are more likely to represent the international transmission of noises which cannot be explained be economic linkages. Hence, it is interesting to look into how macroeconomic fundamentals and other factors influence the international stock market integration.

In this study, we decompose stock returns into the real economic component representing macroeconomic fundamentals and the equity risk premium components representing financial capital flows ${ }^{[3,7,12,13]}$. The real economic component should display significant correlation if the market integration is actually due to economic forces. On the other hand, if the equity risk premium component dominates, this means that the market integration comes from the financial capital flows mainly ${ }^{[16]}$. Mention that the speculative and noise trading may occur in the international context. Therefore, stock price movements driven by fads and a herd instinct may be transmittable across borders.

The issue addressed in this study is important for some reasons. Firstly, the obvious advantage of stock return decomposition is that we can disentangle the underlying causes of any observed stock market integration and provide further insights into the transmission mechanism concerning how stock markets are integrated. Secondly, as far as we know, there are no studies looking into sources of linkages between emerging and developed markets. This study attempts to fill this gap by examining the relationship between the Taiwan and U.S. stock markets.

\section{MATERIALS AND METHODS}

The monthly data on the Taiwan Stock Exchange Capitalization Weighted Stock Index (TAIEX) and the 
$\mathrm{S}$ and $\mathrm{P} 500$ are retrieved from the AREMOS database compiled by Taiwan Economic Data Center (TEDC) for the period January 1990 through December 2001. This amounts to 144 observations. In addition, the monthly leading economic indicators of Taiwan are obtained from the Council for Economic Planning and Development (CEPD) of Taiwan while the leading economic indicators of U.S., compiled by Minor Civil Division (MCD), are obtained from the Bureau of Economic Analysis (BEA).

Real economic and financial risk factors: Although several macroeconomic variables ${ }^{[25,28]}$ have been empirically proven their effects on stock returns occasionally, there is no consensus of which variable has consistent impacts on stock returns. On the other hand, the leading economic indicators have been found to have significant effects on stock return ${ }^{[22-23]}$ and are constructed consistently by economic authorities according to economic environments. Therefore, we employ leading indicators as a proxy for real economic (macroeconomic) factors.

The financial risk factors, evaluating financial integration $\mathrm{in}^{[3]}$, are represented by the residuals from stock returns with the macroeconomic effects filtered out ${ }^{[17]}$. Indicate that linear combinations of a set of common risk premiums help to forecast excess returns in each country. Thus, if international financial markets are highly integrated, we should find higher correlation between the residuals in different counties.

Decomposition of stock returns: The stock return can be written as the following equation:

$\mathrm{R}_{\mathrm{t}}=\alpha_{0}+\alpha_{1} \mathrm{LI}_{\mathrm{t}}+\varepsilon_{\mathrm{t}}$

where, $R_{t}$ is the stock returns and $L_{t}$ represents the leading indicator. The real economic component is measured by $\alpha_{0}+\alpha_{1} L_{t}$ while the risk premium component is the residual. The residuals in Eq. 1 may correspond to risk premiums due to financial risk suggested by ${ }^{[3]}$.

The relationship between stock markets of Taiwan and U.S. are investigated from two parts. The first part to look at the other part is to examine the relationship of financial integration. Therefore, the testing model is formed as follows:

$\mathrm{TW}_{\mathrm{t}}=\beta+\gamma_{0} \mathrm{US}_{\mathrm{t}}+\gamma \mathrm{US}_{\mathrm{t}-1}+\gamma \mathrm{US}_{\mathrm{t}-2}+\ldots . .+\gamma_{\mathrm{i}} \mathrm{US}_{\mathrm{t}-\mathrm{i}}+\mathrm{e}$

where, $\mathrm{TW}_{\mathrm{t}}$ is stock return, real economic component or risk premium component at time $\mathrm{t}$ of TAIEX and $\mathrm{US}_{\mathrm{t}}$ is stock return, real economic component or risk premium component at time $\mathrm{t}$ of the $\mathrm{S}$ and $\mathrm{P} 500$. Therefore, the simultaneous and lead of the S and P 500 corresponding to TAIEX can be examined from Eq. 2.
The impact of Southeast Asian Financial crisis and deregulation of foreign investment: During the study period, there are two major economic events affecting the Taiwan stock market. One is the deregulation of foreign investments in Taiwan financial markets in 1996 and the other is a Southeast Asian financial crisis in 1997. In March 1996, the Taiwan stock markets are completely open to all investors with no ownership restrictions on any signal firm, including Qualified Foreign Institutional Investors (QFII) and NON-QFII investors ${ }^{[18]}$. Find that capital market liberalizations increase the correlation between local and world markets and reduce the cost of capital. But influences from the liberalization policy on the volatility of stock return are small and insignificant.

Meanwhile, the Southeast Asian financial crisis igniting from the plunge of Thai Baht in 1997 affected worldwide financial markets including the U.S. market. Previous studies showed that the worldwide financial markets become more integrated after the major turbulent economic event ${ }^{[19,20]}$. Furthermore, ${ }^{[21]}$ suggest that contagion between markets occurs as a result of attempts by rational agents to infer information from price changes in other markets. Consequently, the Southeast Asian financial crisis in July 1997 may influence the mechanism between Taiwan and U.S. stock markets.

Considering the impacts of deregulation of foreign investments and the Southeast Asian financial crisis, the following process is formed to examine the relationship between the TAIEX and the S and P 500:

$$
\begin{aligned}
& \mathrm{TW}_{\mathrm{t}}=\beta+\gamma_{0} \mathrm{US}_{\mathrm{t}}+\gamma \mathrm{US}_{\mathrm{t}-1}+\gamma \mathrm{US}_{\mathrm{t}-2}+\ldots . .+\gamma_{\mathrm{i}} \mathrm{US}_{\mathrm{t}-\mathrm{i}}+ \\
& \delta_{1} \mathrm{D}_{1 \mathrm{t}} \mathrm{US}_{\mathrm{t}-1}+\delta_{2} \mathrm{D}_{1 \mathrm{t}} \mathrm{US}_{\mathrm{t}-1}+\delta_{3} \mathrm{D}_{1 \mathrm{t}} \mathrm{US}_{\mathrm{t}-2}+\ldots+\delta_{\mathrm{i}} \mathrm{D}_{1 \mathrm{t}} \mathrm{US}_{\mathrm{t}-\mathrm{i}} \\
& +\theta_{\mathrm{i}} \mathrm{D}_{2 \mathrm{t}} \mathrm{US}_{\mathrm{t}}+\theta_{2} \mathrm{D}_{2 \mathrm{t}} \mathrm{US}_{\mathrm{t}-1}+\theta_{3} \mathrm{D}_{2 \mathrm{t}} \mathrm{US}_{\mathrm{t}-2}+\ldots+\theta_{\mathrm{i}} \mathrm{D}_{2 \mathrm{t}} \mathrm{US}_{\mathrm{t}-\mathrm{i}-1}+\omega_{\mathrm{t}}
\end{aligned}
$$

where, $D_{1 \mathrm{t}}=1$ if $\mathrm{t}$ is post Asian financial crisis in 1997 and $\mathrm{D}_{2 \mathrm{t}}=1$ if $\mathrm{t}$ is after the deregulation of foreign investments in Taiwan in 1996. If the relationship between the TAIEX and the S and P 500 is affected by these two events, then the coefficients associated with dummy variables of events will be significant.

\section{RESULTS AND DISCUSSION}

Table 1 reports the results of the relationship between leading indicators and returns for the TAIEX and the S and P 500. It is obvious that leading indicators have significant relationships with corresponding index returns for both markets. This is consistent with previous studies ${ }^{[22,23]}$. Then, we go on to examine the relationship between the TAIEX and the S and P 500 in terms of index returns, real economic and rick premium factors.

For the index returns and risk premiums, the contemporaneous period is positively significant while the lag two periods is more positively significant for the real economic factor (Table 2). 
Table 1: The relationship between leading indicators and stock returns for the TAIEX and the S and P 500

\begin{tabular}{lll}
\hline $\mathrm{R}_{\mathrm{t}}=\alpha_{0}+\alpha_{1} \mathrm{LI}_{\mathrm{t}}+\varepsilon_{\mathrm{t}}$ & & \\
\hdashline & TAIEX & $\mathrm{S}$ and P 500 \\
\hline$\alpha_{0}$ & -0.0048 & $0.0070^{* *}$ \\
& $(0.0092)$ & $(0.0037)$ \\
$\alpha_{1}$ & $2.2037^{* * *}$ & $1.6093^{* * *}$ \\
& $(0.8143)$ & $(0.7605)$ \\
$\mathrm{R}^{2}$ & 0.0477 & 0.0321 \\
Adjust ed-R & 0.0409 & 0.0252 \\
\hline
\end{tabular}

***: Significant at 1\%, **: Significant at 5\%, *: Significant at $10 \%$. Standard errors are in parentheses. The ${ }^{[24]}$ heteroscedasticityconsistent covariance estimator is used

Table 2: The relationship between the TAIEX and the S and P 500 for index returns, real economic and risk premium factor

$\mathrm{TW}_{\mathrm{t}}=\beta+\gamma_{0} \mathrm{US}+\gamma_{1} \mathrm{US}_{\mathrm{t}-1}+\gamma_{2} \mathrm{US}_{\mathrm{t}-2}+\mathrm{e}_{\mathrm{t}}$

\begin{tabular}{llll} 
& Index returns & Real economic & risk premium \\
\hline $\mathrm{B}$ & -0.0125 & -0.0136 & 0.0007 \\
& $(0.0106) * *$ & $(0.0038)^{* *}$ & $(0.0090)$ \\
$\gamma_{0}$ & 0.8331 & -0.0225 & 0.6836 \\
& $(0.2481)^{* *}$ & $(0.2659)$ & $(0.2486)^{* *}$ \\
$\gamma_{1}$ & 0.1093 & 0.2277 & 0.1385 \\
& $(0.2258)$ & $(0.2704)$ & $(0.2484)$ \\
$\gamma_{2}$ & -0.0372 & 0.76168 & -0.0114 \\
$\mathrm{R}^{2}$ & $(0.2258)$ & $(0.2877)^{* *}$ & $(0.2098)$ \\
Adjust ed- ${ }^{2}$ & 0.0968 & 0.0591 & 0.0654 \\
***: Significant at 1\%, **: Significant at 5\%, *: Significant at 10\%. \\
\multicolumn{2}{l}{ Standard errors are in parentheses. The ${ }^{[24]}$ heteroscedasticity- } \\
\multicolumn{2}{l}{ consistent covariance estimator is used }
\end{tabular}

Table 2: The relationship between the TAIEX and the S and P 500 for index returns, real economic and risk premium factor

$\mathrm{TW}_{\mathrm{t}}=\beta+\gamma_{0} \mathrm{US}_{\mathrm{t}}+\gamma_{1} \mathrm{US}_{\mathrm{t}-1}+\gamma_{2} \mathrm{US}_{\mathrm{t}-2}+\delta_{1} \mathrm{D}_{1 \mathrm{t}} \mathrm{US}_{\mathrm{t}}+\delta_{2} \mathrm{D}_{1 \mathrm{t}} \mathrm{US}_{\mathrm{t}-1}+\delta_{3} \mathrm{D}_{1 \mathrm{t}} \mathrm{US}_{\mathrm{t}-}$ ${ }_{1}+\theta_{1} D_{2 t} U_{t}+\theta_{2} D_{2 t} U_{t-1}+\theta_{3} D_{2 t} U_{t-2}+\omega_{t}$

\begin{tabular}{|c|c|c|c|}
\hline & Index returns & Real economic & risk premium \\
\hline B & $\begin{array}{l}-0.0137 \\
(0.0116)\end{array}$ & $\begin{array}{l}-0.0133 \\
(0.0037)^{* *}\end{array}$ & $\begin{array}{l}0.0003 \\
(0.0097)\end{array}$ \\
\hline$\Gamma_{0}$ & $\begin{array}{l}0.9977 \\
(0.6703)\end{array}$ & $\begin{array}{l}-0.1764 \\
(0.3006)\end{array}$ & $\begin{array}{l}0.7737 \\
(0.6881)\end{array}$ \\
\hline$\Gamma_{1}$ & $\begin{array}{l}0.1212 \\
(0.6426)\end{array}$ & $\begin{array}{l}0.1492 \\
(0.2769)\end{array}$ & $\begin{array}{l}0.2261 \\
(0.6910)\end{array}$ \\
\hline$\Gamma_{2}$ & $\begin{array}{l}-0.3440 \\
(0.5134)\end{array}$ & $\begin{array}{l}0.7484 \\
(0.3285)^{* *}\end{array}$ & $\begin{array}{l}-0.0595 \\
(0.4891)\end{array}$ \\
\hline$\Delta_{1}$ & $\begin{array}{l}-0.0806 \\
(0.3139)\end{array}$ & $\begin{array}{l}-0.3726 \\
(1.2092)\end{array}$ & $\begin{array}{l}-0.0851 \\
(0.3328)\end{array}$ \\
\hline$\Delta_{2}$ & $\begin{array}{l}-0.2941 \\
(0.3983)\end{array}$ & $\begin{array}{l}-0.3143 \\
(1.2499)\end{array}$ & $\begin{array}{l}0.0653 \\
(0.4550)\end{array}$ \\
\hline$\Delta_{3}$ & $\begin{array}{l}-0.7427 \\
(0.3575)^{* *}\end{array}$ & $\begin{array}{l}-0.3602 \\
(1.4464)\end{array}$ & $\begin{array}{l}-0.2827 \\
(0.4370)\end{array}$ \\
\hline$\Theta_{1}$ & $\begin{array}{l}-0.1721 \\
(0.6778)\end{array}$ & $\begin{array}{l}0.6722 \\
(1.0830)\end{array}$ & $\begin{array}{l}-0.0563 \\
(0.7207)\end{array}$ \\
\hline$\Theta_{2}$ & $\begin{array}{l}0.2176 \\
(0.6870)\end{array}$ & $\begin{array}{l}0.3993 \\
(1.0730)\end{array}$ & $\begin{array}{l}-0.1891 \\
(0.7896)\end{array}$ \\
\hline$\Theta_{3}$ & $\begin{array}{l}1.0625 \\
(0.5549)^{*}\end{array}$ & $\begin{array}{l}0.0796 \\
(1.3758)\end{array}$ & $\begin{array}{l}0.3108 \\
(0.5956)\end{array}$ \\
\hline $\mathrm{R}^{2}$ & 0.1116 & 0.0880 & 0.0674 \\
\hline Adjust ed- $\mathrm{R}^{2}$ & 0.0506 & 0.0254 & 0.0331 \\
\hline
\end{tabular}

This suggests that the S and P 500 influences the TAIEX at the same time when observing the index movement and the main driving force comes from the risk premium transmission. Also, this reflects the fact that the financial capital flow is the dominant mechanism between the TAIEX and the S and P 500. Hence, these two markets are closely financially integrated. This observation is not surprising since the worldwide financial capital tends to move more frequently and easily due to the trend of capital flow deregulation.

As for the real economic factor, the empirical result shows that the influence of the $\mathrm{S}$ and $\mathrm{P} 500$ variations will take longer to be impounded into the TAIEX. Moreover, the real economic effect from the $\mathrm{S}$ and $\mathrm{P}$ 500 to the TAIEX cannot be found through the index movement. Therefore, changes in the macroeconomic condition of the U.S. will not immediately influence the Taiwan stock market. And the real economic effect may not be substantial in the transmission mechanism between both markets.

Table 3 presents results regarding whether two major economic events alter the transmission mechanism between the TAIEX and the S and P 500. For the real economic and rick premium effects, there are no changes in the transmission mechanisms due to these two major events. The only impact of these two events is to prolong the effect of index changes of the $S$ and P 500 on the TAIEX index changes.

\section{CONCLUSION}

Why do international stock markets exhibit longterm comovements? Are the comovements due to economic fundamentals or pure international capital flows searching for hedge? To answer these questions, the transmission mechanisms of distinct sources should be identified and investigated.

We decompose stock returns into real economic and equity risk premium factors and investigate their respective linkage relationships. Such decomposition allows us to gain more insights of how the international financial markets are linked. And we study the relationship between the Taiwan and the U.S. stock markets since their stock market comovement is consistently observed and there is no such an analytic method applied to study the association of the developed market with the emerging market.

The empirical evidence shows that both real economic fundamentals and equity risk premiums contribute to the linkages of both markets. In addition, the equity risk premiums of the $\mathrm{S}$ and $\mathrm{P} 500$ have a simultaneous effect on the TAIEX while the real economic effect of the S and P 500 to the TAIEX may take longer to be impounded in. Meanwhile, the major factor affecting the transmission from the S and P 500 to the TAIEX is the financial capital flow. That is, the financial integration between the Taiwan and the U.S. stock markets is much stronger than the real economic integration. The deregulation of foreign investments in Taiwan and the Southeast Asian financial crisis in 1997 
did not alter the transmission mechanisms of real economic and equity risk premium factors.

\section{REFERENCES}

1. Simon, W., 1998. Some tests of international equity integration. J. Finan. Econ., 21: 177-212.

2. Mervyn, K., E. Sentana and S Wadhwani, 1994. Volatility and links between national stock markets. Econometrica, 62: 901-933.

3. Ammer, J. And J. Mei, 1996. Measuring international economic linkages with stock market data. J. Finan., 51: 1743-1763.

4. Longin, F. And B. Solnik, 2001. Extreme correlation of international equity markets. J. Finan., 56: 649-676.

5. Arshanapalli, B. And J. Doukas, 1993. International stock market linkages: Evidence from the pre-and post October 1987 period. J. Bank. Finan., 17: 193-208.

6. Kwan, A.C., A.B. Sim and J.A. Cotsomitis, 1995. The causal relationship between equity indices on world exchanges. Applied Econ., 27: 33-37.

7. Dickinson, D.G., 2000. Stock market integration and macroeconomic fundamentals. Applied Finan. Econ., 10: 73-85.

8. Gregory, K., 1996. Modeling the dynamic interdependence of major European stock markets. J. Bus. Finan. Account., 23: 975-988.

9. Kofman, P. And M. Martens, 1997. Interaction between stock market. J. Int. Money Finan., 16: 387-414.

10. Asimakopoulos, I., J. Goddard and S. Costas, 2000. Interdependence between the US and major European equity market: Evidence form spectral analysis. Applied Finan. Econ., 10: 41-47.

11. Campbell, J.Y., 1991. A variance decomposition for stock returns. Econ. J., 101: 157-179.

12. Cheng, A.S., 1998. International correlation structure of financial market movement. Applied Finan. Econ., 8: 1-12.

13. Cheung, Y.W. and K.S. Lai, 1999. Macroeconomic determinate of long-term stock market comovements among major EMS countries. Applied Finan. Econ., 9: 73-85.

14. Yakov, A., M. Haim and W. Robert, 1990. Liquidity and the 1987 stock market crash. J. Portfolio Mange., 16: 65-69.
15. Jeremy, J.S., 1992. Equity risk premium, corporate profit forecasts and investor sentiment around the stock crash of October 1987. J. Bus., 65: 557-570.

16. Shiller, R.J., F. Kolnya and Y. Tsutsui, 1991. Investor behavior in the October 1987 stock market crash: The case of Japan. J. Japanese Int. Econ., 5: $1-13$.

17. Campbell, J.Y. and Y. Hamao, 1992. Predictable returns in the United States and Japan: A study of long term capital market integration. J. Finan., 47: 43-70.

18. Bekaert, G and C. Harvey, 2000. Foreign speculators and emerging equity markets. J. Finan., 55: 656-613.

19. Diamond, J.M., F.A. Abdullah and K.A. Olson, 1997. Portfolio asset allocation process: International diversification by country or by sector. Int. J. Commerce Mange., 7: 39-55.

20. Meric, I. And G. Meric, 1997. Co-movements of European equity markets before and after the 1987 crash. Multinational Finan. J., 1: 137-152.

21. King, M.A. and S. Wadhwani, 1990. Transmission of volatility between stock market. Rev. Finan. Stud., 3: 5-33.

22. Koutoulas, G. And L. Kryzanowski, 1994. Integration or segmentation of the Canadian stock market: Evidence based on the APT. Can. J. Econ., 24: 329-352.

23. Chiang, M.H. and C.Y. Wang, 2002. The impact of futures trading on spot index volatility: Evidence for Taiwan index futures. Applied Econ. Lett., 9: 381-385.

24. White, H., 1980. A heteroscedasticity-consistent covariance matrix estimator and a direct test for heteroscedasticity. Econometrica, 48: 817-838.

25. Chen, N.F., R. Roll and S.A. Ross, 1986. Economic forces and stock market. J. Bus., 59: 383-403.

26. Breen, W., L.R. Glosten and R. Jagannathan, 1989. Economic significance of predictable variations in stock index returns. J. Finan., 44: 1177-1189.

27. Schwert, GW., 1989. Why does stock market volatility change over time? J. Finan., 44: 11151154.

28. Hsieh, D.A. and M.H. Miller, 1990. Margin regulation and stock market volatility. J Finan., 45: 3-29. 